\title{
RELATIONSHIP OF FAMILY ECONOMIC STATUS WITH CHRONIC ENERGY DEFICIENCY IN PREGNANT WOMEN IN JETIS COMMUNITY HEALTH CENTER, YOGYAKARTA
}

\author{
Ni Luh Srinadi'), Theresia Puspitawati²), Nonik Ayu Wantini') \\ 1)Study Program in Diploma DIV, Faculty of Health Sciences, \\ Universitas Respati Yogyakarta \\ 2)Study program of Public Health, Faculty of Health Sciences, \\ Universitas Respati Yogyakarta
}

\begin{abstract}
Background: Four nutritional problems are still major health problem in Indonesia, namely Chronic Energy Deficiency (KEK), Iron Nutritional Anemia (AGB), Disorders Due to Iodine Deficiency (IDD), and Vitamin A Deficiency (KVA). This study aimed to determine the relationship of family economic status with chronic energy deficiency in pregnant women in Jetis community health center, Yogyakarta.

Subjects and Method: This was a cross sectional study conducted at Jetis community health center, Yogyakarta. A sample of 73 was selected by Accidental Sampling. The data were collected by questionnaire and analyzed by Chi Square.

Results: The incidence of chronic energy deficiency with low-income families (71.2\%), and in the middle economic status the incidence of chronic energy deficiency in pregnant women (92.6\%). It was statistically significant $(\mathrm{p}<0.001)$

Conclusion: There is a relationship between families' economic status and the incidence of chronic energy deficiency (CED) among pregnant women visiting Community Health Center of Jetis, Yogyakarta.
\end{abstract}

Keywords: economic status, incidence of chronic energy deficiency (CED), pregnant women.

\section{Correspondence:}

Theresia Puspitawati. Study program of Public Health, Faculty of Health Sciences, Universitas Respati Yogyakarta. E-mail: thpuspitawati@gmail.com. Mobile: +628122719110.

The $7^{\text {th }}$ International Conference on Public Health

Solo, Indonesia, November 18-19, 2020 | 227 https://doi.org/10.26911/the7thicph.03.47 